\title{
Restriction on the re-export of medicinal products and the supervision of compliance with it by public administration bodies
}

Original Paper

\author{
${ }^{1}$ Comenius University in Bratislava, \\ Faculty of Management \\ Department of Information Systems, \\ Bratislava, Slovak Republic \\ ${ }^{2}$ School of Economics and Management of Public \\ Administration in Bratislava \\ Department of Small and Medium Entrepreneurship, \\ Bratislava, Slovak Republic \\ ${ }^{3}$ Comenius University in Bratislava, Faculty of Law \\ Department of Administrative Law and Enviromental Law, \\ Bratislava, Slovak Republic \\ ${ }^{4}$ Matej Bel University, Faculty of Economics \\ in Bratislava, Department of Public \\ Economics and Regional Development, \\ Banská Bystrica, Slovak Republic
}

Peráček T. ${ }^{1 凶}$, Vojtech F. ${ }^{2}$, Srebalová M. ${ }^{3}$, Pekár B. ${ }^{3}$, Mikušová-Meričková B. ${ }^{4}$, Horvat M. ${ }^{3}$

Received 4 April, 2017, accepted 12 May, 2017

Abstract After years of mainly expert discussions (not only in the Slovak legal environment), the concept of and legislation on re-export offer a sort of solution provided for in the Act no. 306/2016 Coll. Said act amends the key legislation in this field, namely the Act no. 362/2011 Coll. on Medicinal Products and Medical Devices and on the amendment of certain acts, as amended (hereinafter referred to as the "Act on Medicinal Products") and the Act no. 363/2011 Coll. on the Scope and Conditions of Payments for Medicinal Products, Medical Devices and Dietetic Foods from Public Health Insurance and on the amendment of certain acts, as amended (hereinafter referred to as the "Act on Payments"). The topic of the paper belongs in the area of medicinal products and pharmaceutical services, it offers, however, significant overlaps in the area of the constitutional, administrative and European law and is aimed at multidisciplinary research into the issue of the reverse export (re-export) of medicinal products. Besides these laws, also the Constitution of the Slovak Republic ("SR") and the sources of the European Law have to be taken into account in relation to the subject in question. The main aim of legislation in this area of law was restriction on the re-export of selected products and protection of patients from adverse impacts of such business activity. The aim of the paper is the authors' effort to analyse the issue of the re-export of medicinal products within the context of the adopted Act no. 306/2016 Coll., whose legislative solution is inevitable for the protection of life and health of the population of the Slovak Republic.

Keywords Re-export of medicinal products - pharmaceutical services-protection of life and health-right to free enterprise - administrative law

\section{METHODS}

Paper contains analysis and comparison of the legislation Slovak law and European Union law - in the field of medicinal products.

Paper defines problems of legislation in terms of legal practice.

Paper gives synthesis of the findings, summarisation and drawing of conclusions (in order to protect a public interest (patient)).

\section{INTRODUCTION}

The organisation of health care, provision of health care or the assurance of the right to health from the point of view of the comparative constitutional law constitutes only a rare subject of legislation in the member states of the European Union. If the Constitution of the Slovak Republic contains provisions that prove that its proposers did not fully understand social changes that were supposed to have taken place after the November of 1989 as a natural and inevitable

*E-mail: tomas.peracek@fm.uniba.sk

(c) European Pharmaceutical Journal 
transition from the socialist to the capitalist society, then such provisions especially include the blunt wording of Article 40 of the Constitution of the SR. If in the phase of interpretation and application of the law the SR has legal provisions on fundamental rights and freedoms that are far from being applied, thus indicating shortcomings in the fulfilment of the model of material rule of law, it is again the provisions of Article 40 of the Constitution of the SR. When the Constitution of the SR was being adopted, the then Slovak National Council contented itself with a wording granting everybody the right to the protection of health. On the basis of health insurance, the right to free health care and to medical devices is only guaranteed to citizens of the SR under conditions set out in the law. Pharmaceutical care, i.e. especially the availability of medical products, forms an integral part of this right guaranteed by the constitution. (Drgonec, 2012)

However, via Article 55 (2) of the Constitution of the SR the Slovak Republic protects and supports competition, which is an inevitable part of every market economy. However, the behaviour of undertakings is not always in conformity with ethical principles. The right to conduct free enterprise is also interpreted very extensively by many distributors of medicinal products, who aim to maximise their profits and seek to export selected types of medicinal products abroad after their import into to the territory of the SR instead of supplying them to pharmacies and hospitals. Available information shows that more medicinal products were re-exported in 2015 than in 2014, when this figure exceeded one million packages. These alarming figures were provided by the State Institute for Drug Control (Štátny ústav pre kontrolu liečiv ŠÚKL), to which planned exports have to be reported. Its figures show that 589 medicinal products numbering nearly 1.4 million packages were exported from the Slovak Republic in 2015, which is nearly 400 thousand more than in 2014. In 2016 these figures grew again, with 700 medicinal products in more than 1.2 million packages in the first two quarters of 2016. The exporters' target was countries of Western Europe, where their price is incomparably higher. (TERAZ.SK, 2016)

The State Institute for Drug Control was authorised to prohibit the export of a medicinal product pursuant to already ineffective legislation, i.e. only until 31 December 2016 , however, only if it threatened to be unavailable on the domestic market. For comparison, according to the opinions of the ŠÚKL, on the basis of import, export and planned export figures, it prohibited the export of 27 medicinal products in 2014 with 182 decisions, which represented 57,446 packages and in 2016 it prohibited the export of a medicinal product as many as 1,700 times. (Dôvodová správa, 2016)

The Ministry of Health of the SR identified several problems causing the unavailability of medicinal products. These especially include bad logistics between the pharmacy and the distributor, problems in the production of a medicinal product or in the distribution chain, as well as the undeniable fact that imported medicinal products are re-exported abroad. The reexport of medicinal products, which substantially contributed to the unavailability of certain medicinal products in Slovakia, especially includes medicinal products for treatment of serious diseases such as epilepsy, schizophrenia, Parkinson's disease or several medicinal products for treatment of oncologic diseases.

Also the Slovak Chamber of Pharmacists has been pointing to this negative trend for years, saying that significantly lower prices in comparison to other EU states, the ability of pharmacies to sell medicinal products also to entities other than patients, as well as the ability of distributors to export medicinal products abroad were the basis for the re-export of medicinal products, which were subsequently unavailable to Slovak patients. It is possible to agree with the opinion of the Association of Innovative Pharmaceutical Industry (Asociácia inovatívneho farmaceutického priemyslu - AIFP), which says that this situation was caused mainly by the fact that prices of medicinal products in Slovakia are some of the lowest in the world, which makes our market attractive for distribution firms. Member companies of the AIFP do not take part in the re-exports and always import a sufficient quantity of medicinal products to Slovakia as determined by statistical estimates of morbidity.

The Slovak Republic was the only one of member states of the European Union to legislatively introduce the possibility to prohibit the export of medicinal products, which is why their export has been monitored since 2013. The European Commission believes that this legislative measure is contrary to the legal order of the European Union, which led to the launch of infringement proceedings against the Slovak Republic. By letter of March 2015 the European Commission asked the SR to provide an answer to justify its viewpoint and demonstrate the compliance of the Slovak legislation with the EU law, especially in relation to the rules on free movement of goods. (Dôvodová správa, 2016)

\section{LEGISLATIVE MEASURES}

Despite the opposition by the European Commission the Ministry of Health of the SR developed a draft law amending:

- the Act no. 362/2011 Coll. on Medicinal Products and Medical Devices and on the amendment of certain acts, as amended (hereinafter referred to as the "Act on Medicinal Products") and

- $\quad$ the Act no. 363/2011 Coll. on the Scope and Conditions of Payments for Medicinal Products, Medical Devices and Dietetic Foods from Public Health Insurance and on the amendment of certain acts, as amended (hereinafter referred to as the "Act on Payments").

The aim of this law is to prevent the re-export of medicinal products and remove the reservations of the European Commission, thus bringing the Slovak legislation regarding medicinal products for human use into compliance with the Treaty on the Functioning of the European Union. Said 
draft law was submitted by the Government of the SR to the National Council of the SR for approval as part of its legislative initiative. The Parliament approved this draft law, which was subsequently promulgated under document number $306 / 2016$ in the Collection of Laws of the Slovak Republic on 23 November 2016 with an effective date from 1 January 2017 (hereinafter referred to as the "amendment").The vacation legis, i.e. the time period for the addressees to acquaint themselves with the content of this new act, is 38 days, which is sufficient given the extensive nation-wide discussion (Mrva et al., 2009)

\section{CONTENT AND SIGNIFICANCE OF THE AMENDMENT}

Right at the outset the amendment supplements the Act on Medicinal Products with the new term "medical prescription in an anonymised form". It is a copy of an issued medical prescription through which a medicinal product for human use included in the list of categorised medicinal products was prescribed to a patient and on which the holder of a licence to provide pharmaceutical care in a public pharmacy or in a hospital pharmacy or a person authorised by a holder of a licence to provide pharmaceutical care in a public pharmacy or in a hospital pharmacy anonymises the patient's personal information. The pharmacy subsequently attaches this copy of a medical prescription to the order addressed to the registration holder via an information system providing automated electronic placement, reception and confirmation of orders of medicinal products for human use included in the list of categorised medicinal products created and operated by the registration holder.

The Act toughens sanctions regarding when after a repeated infringement of an obligation imposed by this act a licence issued to a holder of a licence for the wholesale distribution of medicinal products for human use and to a holder of a licence to provide pharmaceutical care in a public pharmacy or in a hospital pharmacy is obligatorily legally revoked. Further, the words "exporter of a medicinal product" were deleted from the Act on Medicinal Products, because only a holder of a licence to manufacture medicinal products may be an applicant for the issue of a certificate that the manufacturer of a medicinal product is a holder of a licence to manufacture medicinal products and that the holder of a licence to manufacture medicinal products meets applicable provisions of the World Health Organization relating to the manufacture of medicinal products intended for export to third states. It is specified more precisely, to which entities a holder of a licence for the wholesale distribution of medicinal products for human use may supply medicinal products for human use included in the list of categorised medicinal products. The obligation to deliver an ordered medicinal product to a pharmacy within 24 hours imposed on a holder of a licence for the wholesale distribution of medicinal products for human use has been deleted, too. This obligation is only imposed on the holder of the registration of the ordered medicinal product.
New obligations are imposed on a holder of a licence for the wholesale distribution of medicinal products for human use. A holder of a licence for the wholesale distribution of medicinal products for human use is, just as a holder of the registration of a medicinal product, obliged to supply a categorised medicinal product only to a holder of a licence to provide pharmaceutical care in a public pharmacy or in a hospital pharmacy or to another holder of a licence for the wholesale distribution of medicinal products for human use. Should it supply a categorised medicinal product to another holder of a licence for the wholesale distribution of medicinal products for human use, it is obliged to supply the medicinal product to it only for the purposes of final delivery to a holder of a licence to provide pharmaceutical care in a public pharmacy or in a hospital pharmacy.

As part of resale, a holder of a licence for the wholesale distribution of medicinal products for human use is authorised to return excessively categorised medicinal products to the holder of their registration, which constitutes the only exception when these medicinal products may be directed elsewhere than to a pharmacy or another wholesale distributor. Upon request, a holder of a licence for the wholesale distribution of medicinal products for human use is obliged to submit to the Ministry of Health of the SR records of the receipt of medicinal products for human use included in the list of categorised medicinal products and their deliveries:

- $\quad$ to holders of a licence to provide pharmaceutical care in a public pharmacy or in a hospital pharmacy,

- to other holders of a licence for the wholesale distribution of medicinal products for human use and to holders of the registration of these medicinal products in the case of their resale

or data from these records in an electronic format allowing automated processing. Furthermore, a holder of a licence for the wholesale distribution of medicinal products for human use is obliged to keep and retain documentation showing to which qualified entities it has supplied categorised medicinal products and is obliged to submit this documentation or requested data therefrom upon request to the Ministry of Health of the SR in an electronic format. These new obligations imposed on a holder of a licence for the wholesale distribution of medicinal products for human use, relating to categorised medicinal products, are meant to prevent the export of these medicinal products and are in compliance with Article 81 of the Directive 2001/83/EC of the European Parliament and of the Council on the Community code relating to medicinal products for human use. We believe that this provision does not prevent the application of stricter requirements laid down by the member states in relation to the wholesale distribution of: narcotic drugs or psychotropic substances in their territory, medicinal products manufactured from blood, immunological medicinal products and radioactive medicinal products. 


\section{EXPORT OF A MEDICINAL PRODUCT FOR HUMAN USE INCLUDED IN THE LIST OF CATEGORISED MEDICINAL PRODUCTS}

Legal philosophy notes that no power may reach further than its purpose requires. The power holder - in this case the state must respect the dignity of every person and its fundamental civil rights, i.e. also the right to conduct business, which may be statutorily restricted but cannot be abolished (Peráček 2014). This doctrine was respected also by the legislator and the provision of Section 19a of the Act on Medicinal Products was substantially changed by the amendment with the aim to regulate the issue of the export of a medicinal product for human use with a new wording deleting provisions which the European Commission criticized most as discriminatory and unfair. Pursuant to Section 19a of the Act on Medicinal Products, the export of a medicinal product for human use included in the list of categorised medicinal products from the Slovak Republic is understood to mean the export of a medicinal product for human use included in the list of categorised medicinal products to another member state or to a third state. However, the legislator also defined this concept negatively enshrining in the legislation that the resale of a medicinal product for human use included in the list of categorised medicinal products or the return of a medicinal product for human use included in the list of categorised medicinal products, namely due to the assertion of claims for defects of the medicinal product for human use delivered or due to the withdrawal of a medicinal product for human use from the market, is not considered as export. It would constitute disproportionate interference with the buyer's rights, especially in the case of liability for the seller's, i.e. the distributor's defects. A medicinal product for human use included in the list of categorised medicinal products may only be exported by the holder of a licence to manufacture medicinal products that has manufactured the medicinal product being exported, the holder of the registration of this medicinal product or a holder of a licence for the wholesale distribution of medicinal products for human use may also only export if it has been authorised to export a medicinal product for human use included in the list of categorised medicinal products by the holder of the registration of this medicinal product via a written power of attorney. From the point of view of the civil law theory, power of attorney constitutes a unilateral legal act addressed to third persons which certifies the existence and scope of the authorised representative's authorisation to act on behalf and for the person represented. (Cirák et al., 2009) Act is issued separately for each export of a medicinal product for human use included in the list of categorised medicinal products and must contain the name of the medicinal product for human use, its code assigned by the State Institute, the size, the number of packages of the medicinal product for human use and the batch number, the name of the state into which the medicinal product for human use is being exported and the date by which the export is supposed to take place. Furthermore, the holder of the registration of the medicinal product for human use is obliged to notify its export in an electronic format to the State Institute not later than seven days after the export takes place. After the reception of this notification, the State Institute immediately publishes the export of the medicinal product for human use included in the list of categorised medicinal products on its website. A special situation applies to the export of a medicinal product for human use included in the list of categorised medicinal products for the needs of the Armed Forces of the Slovak Republic, Armed Security Corps and the Fire and Rescue Corps to ensure the fulfilment of their tasks outside the territory of the Slovak Republic under specific legislation.

The resale of medicinal products, which pharmacies normally used to perform as one of their activities, namely to any holder of a licence for the wholesale distribution of medicinal products for human use, is deleted from the pharmaceutical care. The medicinal product may only be resold to the licence holder the pharmacy purchased the medicinal product from. The exchange of medicinal products for human use from the list of categorised medicinal products is only possible between holders of a licence to provide pharmaceutical care in a public pharmacy or in a hospital pharmacy, but only for the purposes of their issue in a public or hospital pharmacy. The aim of these measures delimiting the scope of activities carried out in a public or hospital pharmacy is to prevent the export of categorised medicinal products, which a holder of registration supplied to the market in the Slovak Republic for the purposes of their issue to the patient in said pharmacies. The problem was that many holders of a licence for the wholesale distribution of medicinal products for human use purchased categorised medicinal products from holders of a licence to provide pharmaceutical care in a public pharmacy or in a hospital pharmacy and subsequently exported them. New obligations are imposed on a holder of a licence to provide pharmaceutical care in a public pharmacy or in a hospital pharmacy. The most important of them is the issue of a categorised medicinal product to a patient. The following are also allowed:

- the resale of these medicinal products to a holder of a licence for the wholesale distribution of medicinal products for human use who supplied them to a holder of a licence to provide pharmaceutical care in a public pharmacy or in a hospital pharmacy,

- the exchange of medicinal products for human use included in the list of categorised medicinal products between holders of a licence to provide pharmaceutical care in a public pharmacy or in a hospital pharmacy for the purposes of their issue in a public or hospital pharmacy.

Another obligation imposed on a holder of a licence to provide pharmaceutical care in a public pharmacy or in a hospital pharmacy is the obligation to order medicinal products for 
human use included in the list of categorised medicinal products from the holder of their registration via an information system providing automated electronic placement, reception and confirmation of orders of medicinal products for human use included in the list of categorised medicinal products if it requires the holder of the registration of a medicinal product for human use to deliver a medicinal product for human use included in the list of categorised medicinal products within 24 hours after the order reception. An anonymised medical prescription has to be attached to the order.

A holder of a licence to provide pharmaceutical care in a public pharmacy or in a hospital pharmacy is obliged to maintain for 10 years records of holders of a licence for the wholesale distribution of medicinal products for human use and holders of the registration of medicinal products for human use from whom it acquired medicinal products for human use included in the list of categorised medicinal products and submit these records or data therefrom upon request to the Ministry of Health of the SR in an electronic format allowing automated processing of these data.

The registration holder has some more obligations e.g. the creation and operation of an information system for ordering medicinal products for which it holds registration. The database provides the holder of the registration of medicinal products for human use with an overview of holders of a licence to provide pharmaceutical care in a public or hospital pharmacy to which it supplied medicinal products included in the list of categorised medicinal products within 24 hours on the basis of an anonymised medical prescription. It is obliged to maintain this information system in operable condition and in case of its outage it is obliged to receive and confirm orders of medicinal products for human use included in the list of categorised medicinal products also in a different manner that will allow it to ensure the delivery of the medicinal product to the pharmacy within 24 hours.

It is further required to deliver medicinal products for human use included in the list of categorised medicinal products within 24 hours to holders of a licence to provide pharmaceutical care in a public or hospital pharmacy on the basis of an order via an information system with an anonymised medical prescription attached. This obligation does not apply to a holder of the registration of a medicinal product for human use who has claims against a holder of a licence to provide pharmaceutical care in a public or hospital pharmacy for delivered medicinal products included in the list of categorised medicinal products after double expiration of the contracted payment due date. The registration holder is obliged to designate as well as notify to the Ministry of Health of the SR a person responsible for the delivery of medicinal products for human use included in the list of categorised medicinal products residing or having its registered office in the territory of the Slovak Republic, if the holder of the registration of medicinal products for human use does nor reside or does not have its registered office in the territory of the Slovak Republic.
The registration holder is obliged to maintain records of holders of a licence for the wholesale distribution of medicinal products for human use and of holders of a licence to provide pharmaceutical care in a public pharmacy or hospital pharmacy to which it supplied medicinal products included in the list of categorised medicinal products. It is obliged to retain also these records for 10 years and submit these records or data therefrom upon request to the Ministry of Health of the SR in an electronic format allowing automated processing of these data. The registration holder is obliged to supply a mandatory medicinal product for human use included in the list of categorised medicinal products to a holder of a licence for the wholesale distribution of medicinal products for human use solely for the purposes of final delivery to a holder of a licence to provide pharmaceutical care in a public pharmacy or in a hospital pharmacy.

The Act grants the Ministry of Health of the SR new powers to publish on its website the name, surname and address of the person responsible for the delivery of medicinal products within 24 hours if it is a natural person or the name or business name and registered office of the person responsible for the delivery of medicinal products within 24 hours if it is a legal person and its contact details consisting of the e-mail address and the mobile phone number.

\section{SUPERVISION BY ADMINISTRATION BODIES AND IMPOSITION OF SANCTIONS FOR INFRINGEMENT OF THE ACT}

The application of the Act added several subject matters of different administrative offences for the infringement of new obligations imposed on the registration holder contained in Section 138 of the Act on Medicinal Products. The Ministry of Health of the SR has new powers to impose fines for different administrative offences regarding the new obligations imposed on a holder of a licence for the wholesale distribution of medicinal products for human use. The procedure for accountability for a different administrative offence is based on the Act on Medicinal Products (special act) in combination with proceedings pursuant to the Code of Administrative Procedure (general legislation) (Horvat, 2014).The Act no. 363/2011 Coll. on the Scope and Conditions of Payments for Medicinal Products, Medical Devices and Dietetic Foods from Public Health Insurance and on the amendment of certain acts has been amended by the Act no. 460/2012 Coll. and the Act no. 265/2015 Coll. has been amended with the aim to bring sanctions pursuant to this act into compliance with different administration offences pursuant to the Act on Medicinal Products.

The Act on Medicinal Products provided significant room for the exercise of the powers of state administration bodies in the field of health care even before the adoption of the Act. The exercise of state administration in the field of human pharmacy is performed by the Ministry of Health of the SR and the State Institute for Drug Control and the state 
administration in the field of human pharmacy in a selfgoverning region is performed as its transferred exercise also by the self-governing region. The Act contains a fairly broad range of sanctions for offences in its eighth part. Proceedings on offences in the field of human pharmacy and their hearing are covered by the Act no. 372/1990 Coll. on Offences, as amended. Besides, public administration bodies may impose sanctions (a fine) up to EUR 1 million for different administrative offences according to the gravity of the misconduct using the procedure laid down in the Act no. 71/1967 Coll. on Administrative Proceedings (Code of Administrative Procedure), as amended. However, within the administrative judicial system, persons concerned may require the court to review the lawfulness of the decision to impose a sanction. (Ficová et al., 2010)

\section{BRINGING THE ACT INTO COMPLIANCE WITH EUROPEAN UNION LAW}

One of the fundamental principles of the functioning of the European Union is the development of social policy also in member states. This idea is contained in the Treaty of Rome of 1957 establishing the European Economic Community (Vojtech \& Levický, 2016). Pursuant to the second sentence of Article 7 (2) of the SR Constitution, legally binding acts of the European Communities and European Union take precedence over the laws of the Slovak Republic, which was also respected by the legislator, which is why the wording of the Act is fully in accordance with European Union law (Gregušová \& Peráček, 2015). The free movement of goods, which includes medicinal products, constitutes the first of the four fundamental freedoms of the internal market, which derives its legal basis from Articles 26, 28 to 37 of the Treaty on the Functioning of the European Union. It is guaranteed especially by the abolition of the customs duties and quantitative restrictions as well as by the prohibition of measures having equivalent effect. To support the completion of the internal market, principles of mutual recognition, abolition of physical and technical constraints and standardisation support were added. The adoption of the new legislative framework in 2008 significantly reinforced the marketing of products, the free movement of goods, the system of surveillance over the European Union market and the CE marking. The right to the free movement of goods originating in member states and third countries that are in free circulation in member states is one of the fundamental principles of the Treaty (Article 28 of the TFEU). Originally, the free movement of goods was considered to be part of the customs union between the member states, which included the abolition of customs duties, quantitative restrictions and measures having equivalent effect and the introduction of a common customs tariff of the Community. Later, attention was focused on the abolition of all remaining constraints of free movement with the aim to create an internal market - space without internal borders in which goods could move just as freely as on the national market (Nováčková \& Milošovičová, 2011).

\section{CONCLUSION}

Legal opinions of the issue of the limitation of the free movement of medicinal products within member states are not and will never be uniform. It is possible to agree with the view that freedom to conduct business cannot be understood as an absolute right without any limitation. (Mucha et al., 2016) It is because this freedom also has its own content, which may be affected by a state intervention which may not necessarily be unlawful or discriminatory from the point of view of the Community law. From the point of view of exporters of medicinal products, it is evident that they understand such intervention by the legislator as a denial of the foundation of free enterprise when they are stripped of the possibility to export medicinal products from the Slovak Republic to another EU member state. Such intervention may, however, only be justified by legitimately invoking the general nation-wide interest because the task of a fair society and its institutions, on which it is based, is to develop a framework where individuals will be guaranteed conditions inevitable for them to achieve what they themselves consider good, i.e. the right to available health care (Chovancová, 2009). The right to conduct business in the area of import and export of medicinal products is not generally being prohibited by the legislator; it is only being limited in certain situations as the Slovak Republic guarantees everybody the right to the protection of health pursuant to the first sentence of Article 40 of the SR Constitution. This right, which applies both to the citizens of the Slovak Republic and to foreigners regardless of their nationality, must always take precedence over anybody's right to conduct business and make profit regardless of possible consequences (Peráček et al., 2016).

\section{References}

[1] Cirák J et al. Občianske právo : všeobecná čast'. Šamorín, Heuréka; 2008

[2] Dôvodová správa k návrhu zákona č. 306/2016 Z. z., ktorým sa mení a doplña zákon č. 362/2011 Z. z. o liekoch a zdravotníckych pomôckach a o zmene a doplnení niektorých zákonov v znení neskorších predpisov a ktorým sa mení zákon č. 363/2011 Z. z. o rozsahu a podmienkach úhrady liekov, zdravotníckych pomôcok a dietetických potravín na základe verejného zdravotného poistenia a o zmene a doplnení niektorých zákonov v znení neskorších predpisov,

[3] Drgonec J. Ústava Slovenskej republiky. Komentár. 3. vydanie. Šamorín, Heréka; 2012

[4] Ficová $S$ et al. Občianske súdne konanie. - 1. vyd. Praha, C. H. BECK; 2010 
[5] Gregušová D, Peráček T. Obchodné právo pre manažérov: Právne postavenie podnikatela podla Obchodného zákonníka; obchodné spoločnosti a družstvo. 2. dopl. a prepracované vyd. Bratislava, Univerzita Komenského v Bratislave; 2015

[6] Horvat M. Vybrané kapitoly zo správneho práva. Bratislava, Ekonóm; 2014

[7] Chovancová J. Liberalizmus verzus komunitarizmus. Bratislava, Univerzita Komenského v Bratislave; 2009

[8] Mrva $M$ et al. Legisvakancia v právnom poriadku Slovenskej republiky. Bratislava, Univerzita Komenského v Bratislave; 2009

[9] Mucha B et al. Podnikatel'ské prostredie na Slovensku so zameraním na malé a stredné podniky. Paper presented at: 9. Mezinárodní vědecká konference dotorandů a mladých vědeckých pracovníků; November 10, 2016; Opava, ČR

[10] Nováčková D, Milošovičová P. Medzinárodné ekonomické právo. Bratislava, Eurounion; 2011
[11] Peráček T et al. Free movement of goods (pharmaceuticals) in the European Union versus protection of health of population. Paper presented at: 17th International scientific conference on economic and social development. "Managerial issues in modern business". October 20-21, 2016; Warshaw, Polland

[12] Peráček T. K sociálno-etickým východiskám problematiky spravodlivosti. Paper presented at: Den právní teorie. April 20, 2014; Brno, ČR .

[13] Minister Drucker chce pre vývoz liekov menit' legislatívu. TERAZ. SK

[14] (http://www.teraz.sk/zdravie/lieky-reexport-novela-druckervyvoz/204956-clanok.html). Revised July 2016. Accessed January 15, 2017

[15] Vojtech F, Levický M. Dimenzia sociálnej politiky $v$ kontexte ekonomickej situácie regiónov EÚ. Brno, Tribún; 2016

Legislation

- zákon č. 71/1967 Zb. o správnom konaní (správny poriadok) v znení neskorších predpisov

- zákon SNR č. 372/1990 Zb. o priestupkoch v znení neskorších predpisov

- ústavný zákon SNR č. 460/1992 Zb. Ústava Slovenskej republiky v znení neskorších predpisov

- zákon č. 306/2016 Z. z., ktorým sa mení a doplña zákon č. 362/2011 Z. z. o liekoch a zdravotníckych pomôckach a o zmene a doplnení niektorých zákonov $v$ znení neskorších predpisov a ktorým sa mení zákon č. 363/2011 Z. z. o rozsahu a podmienkach úhrady liekov, zdravotníckych pomôcok a dietetických potravín na základe verejného zdravotného poistenia a o zmene a doplnení niektorých zákonov $v$ znení neskorších predpisov,
- zákon č. 362/2011 Z. z. o liekoch a zdravotníckych pomôckach a o zmene a doplnení niektorých zákonov v znení neskorších predpisov,

- zákon č. $363 / 2011$ Z. z. o rozsahu a podmienkach úhrady liekov, zdravotníckych pomôcok a dietetických potravín na základe verejného zdravotného poistenia a o zmene a doplnení niektorých zákonov v znení neskorších predpisov. 